\title{
An Assessment of Risk Factors for Early Death Among a Sample of Previously Incarcerated Youth
}

\author{
Patricia A. Stoddard Dare \\ Cleveland State University, p.stoddarddare@csuohio.edu \\ Miyuki Fukushima Tedor \\ Cleveland State University, m.fukushima@csuohio.edu \\ Linda M. Quinn \\ Cleveland State University, I.quinn@csuohio.edu \\ Christopher A. Mallett \\ Cleveland State University, c.a.mallett@csuohio.edu
}

Follow this and additional works at: https://engagedscholarship.csuohio.edu/clsowo_facpub

Part of the Criminal Law Commons, Epidemiology Commons, and the Juvenile Law Commons How does access to this work benefit you? Let us know!

\section{Publisher's Statement}

This is an Accepted Manuscript of an article published in Criminal Justice Studies: A Critical Journal of Crime, Law and Society on 2/14/14 available online: http://www.tandfonline.com/ doi/abs/10.1080/1478601X.2014.885756\#.U3-wvyjCBYU

\section{Recommended Citation}

Stoddard Dare, Patricia A.; Tedor, Miyuki Fukushima; Quinn, Linda M.; and Mallett, Christopher A., "An Assessment of Risk Factors for Early Death Among a Sample of Previously Incarcerated Youth" (2014). Social Work Faculty Publications. 20. https://engagedscholarship.csuohio.edu/clsowo_facpub/20

This Article is brought to you for free and open access by the School of Social Work at EngagedScholarship@CSU. It has been accepted for inclusion in Social Work Faculty Publications by an authorized administrator of EngagedScholarship@CSU. For more information, please contact library.es@csuohio.edu. 


\title{
An assessment of risk factors for early death among a sample of previously incarcerated youth
}

\author{
Patricia Stoddard-Dare ${ }^{\mathrm{a} *}$, Miyuki Fukushima Tedor ${ }^{\mathrm{b}}$, Linda Quinn ${ }^{\mathrm{c}}$ and \\ Christopher Mallett ${ }^{\mathrm{d}}$
}

\begin{abstract}
${ }^{a}$ School of Social Work, Cleveland State University, 2121 Euclid Avenue, CB 320, Cleveland, $\mathrm{OH} 44115$, USA; ${ }^{b}$ Department of Sociology and Criminology, Cleveland State University, 2121 Euclid Avenue, RT 1733, Cleveland, OH 44115, USA; ' Department of Mathematics, Cleveland State University, 2121 Euclid Avenue, RT 1512, Cleveland, OH 44115, USA; ${ }^{d}$ School of Social Work, Cleveland State University, 2121 Euclid Avenue, CB 324, Cleveland, OH 44115, USA
\end{abstract}

(Received 25 November 2013; accepted 16 January 2014)

\begin{abstract}
Most previous research regarding early death prior to, or during, young adulthood among previously detained delinquent youth has focused predominantly on males or on their cause of death. This study extends previous research by evaluating potential factors that are associated with early death in a random sample $(N=999)$ of formerly detained youthful offenders in New York stratified by gender $(50 \%$ female). Existing case records were referenced with the National Death Index to determine if the formerly detained youth were deceased by the time they would have reached age 28 . Regression analyses were run to determine if any of 16 sociodemographic, offense history, weapons/gang involvement, mental health, substance use, child maltreatment, child welfare, or family environmental risk factors measured in their childhood or adolescence were associated with early death. Two additional regression analyses were run to determine if those risk factors differentially impacted early death for males vs. females. Of the variables measured, however, only gender was significantly related to early death - compared to females, males were 2.3 times more likely to have prematurely died. Additionally, in the model run separately for females, being an African-American female was protective against early death. These findings are compared to findings from the existing literature.
\end{abstract}

Keywords: juvenile offender; gender; race; ethnicity; mortality

\section{Introduction}

There are many adverse consequences of juvenile delinquency. Youthful offenders are at higher risk than their non-offending peers for experiencing negative outcomes including injury (Loeber, Kalb, \& Huizinga, 2001; Mernard, 2002), physical illness and disability (Odgers et al., 2007; Piquero, Farrington, Nagin, \& Moffitt, 2010), mental health/substance abuse problems (Corneau \& Lanctot, 2004; Moffitt, Caspi, Harrington, \& Milne, 2002; Siminoff et al., 2004), and premature death (Ezell \& Cohen, 2005; Laub \& Valliant, 2000). Of concern in this study is the population's increased risk of early death during young adulthood. 
In this study, secondary data were used to examine 16 risk factors for early death among individuals detained in their youth. This research is unique because it utilizes a sample that is balanced by gender. It also includes risk factors not previously evaluated in relationship to early death in youthful offenders. Identifying risk factors is important so that targeted interventions can be developed to reduce the risk of early death.

\section{Review of literature}

\section{Delinquency to premature death}

Delinquent youthful offenders are at an increased risk of premature death from all causes. Indeed, the risk of early death among formerly delinquent youthful offenders is two to four times higher than their non-delinquent peers (Lattimore, Linster, \& MacDonald, 1997; Laub \& Valliant, 2000; Piquero, Shepherd, Shepherd, \& Farrington, 2011; Teplin, McClelland, Abram, \& Mileusnic, 2005; Trumbetta, Seltzer, Gottesman, \& McIntyre, 2010; Yeager \& Lewis, 1990). The risk of early death is heightened during the month following release from incarceration (Binswanger et al., 2007; Krinsky, Lathrop, Brown, \& Nolte, 2009; Spaulding et al., 2011). According to Teplin et al. (2005), the most common causes of early death among adjudicated delinquents include homicide $(90.1 \%)$ followed by being killed by a police officer $(5.4 \%)$, suicide $(1.1 \%)$, motor vehicle accidents $(1.3 \%)$, other accidents $(.05 \%)$, or other external causes $(1.6 \%)$.

Given the elevated risk of early death, it is important to investigate those unique factors present in the lives of delinquent youthful offenders that are associated with a higher risk of premature death in young adulthood. Previous research has identified some possible factors that may be related to early death including demographic, child welfare, family environmental, substance use, mental health, weapons/gang, or offense history.

\section{Demographics}

The longitudinal research that follows delinquent youthful offenders and assesses their risk of early death is limited. Previous research, for instance, has often either excluded females entirely (Lattimore et al., 1997; Glueck \& Glueck, 1950, cited in Teplin et al., 2005) or did not include enough females to conduct meaningful analysis by gender (Chassin, Piquero, Losoya, Mansion, \& Schubert, 2013; Yeager \& Lewis, 1990). Similarly, some of the previous research has underrepresented minority youth (Glueck \& Glueck, 1950 cited in Teplin et al., 2005). These are unfortunate limitations because both gender and race/ethnicity have been identified as important correlates of premature death during early adulthood among individuals with a history of juvenile delinquency. Some studies have found that African-American offenders are more likely to die prematurely (Harrell, 2007; Lattimore et al., 1997; Piquero, MacDonald, Dobrin, Daigle, \& Cullen, 2005), but there is reason to believe this risk might vary by gender. Indeed, Teplin et al. (2005) examined mortality rates for 1829 delinquent and non-delinquent adolescents in a longitudinal study with follow-up extending over seven years. The sample was $64 \%$ male, 55\% African-American, and $28 \%$ Hispanic, with an average age at entrance into the juvenile justice system of 14.9 years. Teplin et al. (2005) found mortality rates differ based on race and gender, and males with a history of delinquency were four times more likely to have died 
during follow-up than their comparable non-delinquent male peers. Additionally, delinquent females were almost eight times more likely to die than their comparable non-delinquent female peers. The vast majority $(95.5 \%)$ of these premature deaths among the delinquent population resulted from homicide (Teplin et al., 2005).

\section{Maltreatment and trauma}

Many of the adolescents involved with the juvenile courts have maltreatment histories; that is, they are victims of physical or sexual abuse, or neglect. It is estimated that between 26 and $60 \%$ of juvenile court-involved adolescents have a history of maltreatment, with the higher percentages for those held in detention and/or incarceration facilities (Bender, 2009; Ford, Chapman, Hawke, \& Albert, 2007; Sedlak \& McPherson, 2010; Stouthamer-Loeber, Wei, Homish, \& Loeber, 2002). Repeated maltreatment no matter the type (physical abuse, sexual abuse, or neglect) has a significant impact on youthful offending. Such repeat victimization predicts the initiation, continuation, and severity of delinquent acts (Hamilton \& Browne, 1998; Lemmon, 2006), and is associated with serious, chronic, and violent offending behaviors (Hamilton, Falshaw, \& Browne, 2002; Smith \& Thornberry, 1995). In addition, children who are maltreated during later childhood and adolescence are at even higher risk of committing violent and delinquent acts (Johnson-Reid \& Barth, 2000; Smith, Ireland, \& Thornberry, 2005).

Within juvenile court populations, females are more likely than males to have been victims of sexual abuse, and are equally likely to have experienced physical abuse (Acoca, 1998; Shelton, 2004). The cumulative impact of maltreatment may affect females more negatively than males (Howell, 2003; National Center for Child Traumatic Stress, 2009). However, research findings are not sufficiently conclusive to determine that maltreatment effects for females are greater when compared to males in delinquency development (Zahn et al., 2010).

Child maltreatment-related risk factors that impact offending behavior in adolescents may also impact their risk of premature death during or beyond adolescence. Theorists have posited that children who suffered poor parenting, which would include those children who are involved in the child welfare system are at an elevated risk of early death in adulthood (Laub \& Valliant, 2000). Laub and Valliant (2000) also describe how dysfunctions in the family may contribute to poor self-care habits (e.g. not wearing a seat belt and failure to look both ways when crossing traffic) which may increase early death. Using longitudinal data that followed delinquent youth $(N=475)$ and same age-matched non-delinquent peers $(N=456)$ until age 65 , Laub and Valliant found that abusive and neglectful parenting practices were related to early death among those with a history of delinquency. The impact of other child welfare-related variables on premature death among formerly delinquent youthful offenders, such as receiving child welfare services, foster care placement, foster care placement disruption, and having a family or household member with a criminal history or substance abuse problem is currently unknown but merits further study.

\section{Substance use}

Previous research has demonstrated a link between early death and substance abuse. Lattimore et al. (1997) showed that having a drug-related arrest doubled the 
likelihood of death by homicide in a sample of $N=1998$ formerly delinquent youthful offenders who were followed over a period of 11 years into young adulthood. Similarly, Romanov et al. (1994) found a two times increased risk of early death for those who were substance abusers. Given that many of the prevailing theories explaining substance use disorders point to the impact of family-related variables (e.g. genetics and social learning, see Johnson, 2003), it is also worth investigating the impact of having a family member with a substance abuse problem as a possible risk factor for early death within this population.

\section{Mental health problems}

Previous research has consistently demonstrated that delinquent youthful offenders have a higher prevalence of mental health problems compared to their non-offending peers (Laub \& Valliant, 2000). In fact, a majority of detained and incarcerated youthful offenders have a mental health diagnosis, many of them severe (Grisso, 2008). Common mental health disorders found among incarcerated youth include depressive disorders (between 13 and 40\%), psychotic disorders (between 5 and $10 \%$ ), anxiety disorders (up to $25 \%$ ), attention-deficit hyperactivity disorder (up to $20 \%$ ), disruptive behavior disorders (between 30 and $80 \%$ ), and substance use disorders (between 30 and 70\%) (Abram, Teplin, McClelland, \& Dulcan, 2003; Goldstein, Olubadewo, Redding, \& Lexcen, 2005; Shufelt \& Cocozza, 2006).

Mental health problems are related to mortality in general. Indeed, the National Institute of Mental Health (2012) has indicated that mental health issues are often a causal factor in adolescent and young adults' early death. One obvious cause of early death that is related to mental health is suicide. In fact, delinquent youth attempt suicide at a higher rate than their non-delinquent peers (Epstein \& Spirito, 2009; Thompson, Ho, \& Kingree, 2007). And delinquent females, compared to delinquent males, are at an even greater risk for suicide attempts (Holsinger \& Holsinger, 2005). Moffitt et al. (2001) found that compared to their non-delinquent youthful counterparts, female juvenile delinquents are 3.8 times more likely to attempt suicide and male juvenile delinquents are 1.6 more likely to attempt suicide. This higher prevalence of suicidal behavior among the population with a history of delinquency continues into young adulthood. Corneau and Lanctot (2004) followed a sample of male $(N=292)$ and female $(N=113)$ delinquent youthful offenders from the mean age of 15 for 10 years and found that 20 and $10 \%$, respectively, of the delinquents had attempted suicide during the follow-up period. This risk is confirmed in research conducted by Teplin et al. (2005) which lists suicide as the cause of death in $1.1 \%$ of formerly delinquent youthful offenders.

Another explanation for the link between mental health and early death is decreased impulse control and increased engagement in high-risk behaviors. Laub and Valliant (2000) have hypothesized that early death is related to youthful offenders' increased risk-taking and poor impulse control, which are commonly seen in some mental health disorders. In all, mental health is an important variable to assess its relationship to early death within this population.

\section{Weapons charges and gang affiliation}

Previous research has shown a relationship between gang affiliation and premature death among youthful offenders (Chassin et al., 2013). Illegal use of weapons is 
another possible risk factor for death in early adulthood among juvenile offenders (Chassin et al., 2013; Lattimore et al., 1997). Teplin et al. (2005) found that 90\% of all deaths among the delinquent youthful offenders studied were by firearm. This is alarming and considerably higher than among the general population of adolescents and young adults in the United States. Thus, though weapons charges certainly under-represents all delinquent youthful offenders who interact with firearms, examination of these charges is critical as they are a potential predictor of early death in our sample given the large number of previously delinquent youthful offenders who die in young adulthood by a firearm. If an association is seen between weapons charges and early death, this may also provide an opportunity to target an identifiable group of high-risk individuals for prevention.

\section{Initiation of criminal activity prior to age 14}

Moffitt (1993, p. 674) originally offered a 'dual taxonomy' of developmental pathways that differentiates adolescent-limited and life-course-persistent (LCPs) offenders. Empirical studies testing Moffitt's theories thus far have produced mixed results. In particular, some scholars (e.g. Laub \& Sampson, 2003; Sampson \& Laub, 2005) have questioned the existence of the two distinct groups of delinquents. However, Moffitt's own studies (Moffitt, 1997, 2003; Moffitt et al., 2001, Piquero \& Moffitt, 2005) as well as numerous other researchers (Bartusch, Jeglum, Lynam, Moffitt, \& Silva, 1997; Nagin, Farrington, \& Moffitt, 1995; Tibbetts \& Piquero, 1999) provide some empirical support to the main thrust of her developmental pathway theory.

Since the deceased subjects in this study died young, it is impossible to determine definitively whether they would have been life-course persistent offenders. However, they undoubtedly represent the highest risk youthful offenders among juvenile delinquents given their tragic outcome of early death. An often accepted proxy to identify LCPs among a retrospective longitudinal sample is initiation of criminal activity prior to the age of 14 years (Simons, Wu, Conger, \& Lorenz, 1994; Tibbetts \& Piquero, 1999). It is possible that the youthful offenders in this study who initiated delinquent behavior prior to the age of 14, and LCPs in general, are more prone to experience adverse health consequences and possibly premature death. In fact, Moffitt (2006, p. 57) hypothesizes that the individuals with high antisociality or criminality may be at a higher risk for "poor physical health, cardiovascular disease, and early disease morbidity and mortality.' This is understandable given the theory's emphasis on the health-related disadvantages that LCPs experience early in their lives, which Moffitt states as the cause of the negative disposition. For instance, studies find that brain development disturbances that result in a neurological damage may be caused prenatally by drug abuse (Rodning, Beckwith, \& Howard, 1989) or poor nutrition of mother (Stewart, 1983); both prenatally and after birth by exposure to toxins (e.g. Needleman \& Beringer, 1981), lack of nutrition (Cravioto \& Arrieta, 1983), abuse and neglect (Milner \& McCanne, 1991); or during birth by complications during delivery (Kandel \& Mednick, 1991). Many of these causes, such as poor nutrition and abuse and neglect, in fact may have long-lasting overall health consequences in addition to the immediate neurological damage. Besides individual-trait deficiencies (e.g. low self-control and irritability), empirical studies also find that the individuals who engage in antisocial behaviors tend to experience various social disadvantages that might affect their 
overall health outcomes. For instance, children who have neurological damages often grow up in a negative family environment with abuse and neglect (Hertzig, 1983). Using longitudinal data, Piquero et al. (2007) tested Moffitt's hypothesis, whether or not the LCPs experience a higher level of adverse health outcome. They found that compared to other groups, LCPs show the most negative health outcomes, including psychological distress. Given the inconclusive findings about the impact of distinct life-course pathways to offending, it is valuable to further study its relationship to early death.

\section{Summary of research to date}

Extant research regarding individuals who were adjudicated delinquent in their adolescence has revealed some important findings. Of greatest importance, previous research has demonstrated that delinquent youthful offenders have a significantly higher risk of early death in adulthood compared to their non-delinquent peers. Furthermore, the literature suggests that many interrelated factors that can be assessed during adolescence may be correlated with early death including race, gender, history of maltreatment and child welfare involvement, family environment, substance use, mental health, weapons and gang-related risks, and offense history.

Research exists regarding the risk of death in late adulthood among individuals who were delinquent as adolescents (Nieuwbeerta \& Piquero, 2008; Piquero, Shepherd, Shepherd, \& Farrington, 2011); however, as noted, research examining death in early adulthood among delinquent United States adolescents has been severely limited in scope by a lack of gender and racial inclusiveness (Glueck \& Glueck, 1950 cited in Teplin et al., 2005; Lattimore et al., 1997; Laub \& Valliant, 2000; Piquero et al., 2011). This is salient because gender and race are related to multiple delinquency outcomes. Prior research has been valuable in elucidating the high risk of death within the groups studied, but further research is needed to capture the risk factors associated with early death in males and females adjudicated delinquent in their youth. Findings from this research can be used to provide targeted interventions to delinquent youthful offenders who display risk factors for early death.

\section{Current study}

The present research uses secondary data to bridge the gap in previous research which has examined premature death among former delinquents. This research aims to determine if any of the 16 risk factors measured in their childhood or youth predicted premature death among young adults who have a history of delinquency. Variables available for inclusion were limited to those in the secondary data-set utilized, and were selected based on their relationship to delinquency and adverse health outcomes. A second aim of this research was to determine whether males and females differ in terms of the factors that increase their likelihood of premature death. If early risk factors are identified then at-risk youth can be provided with preventative interventions aimed to decrease their risk of premature death and increase their resiliency.

\section{Methods}

In the current study, an Interuniversity Consortium for Political and Social Research database was utilized. This data-set evolved from the work of Frederick (1999) and 
Colman, Kim, Mitchell-Herzfeld, and Shady (2009) who were responsible for determining which variables would be included in the database as well as sampling, data collection, data coding, and missing data imputation. Their sampling frame included all youthfiul offenders adjudicated delinquent who were released from the New York Division of Youth (now called New York State Office of Children and Family Services OCFS) between 1991 and 1994. All of the sampled youthful offenders resided in a DFY (Division for Youth) facility or private agency. (Details regarding selection of the residential facilities can be found in Frederick, 1999.) From that sampling frame, they selected a random sample of 999 delinquent youthful offenders stratified by gender ( $50 \%$ female) for inclusion in the database.

This database held data extracted from juvenile court and child welfare-related case records (including probation documents, intake assessments, home assessments, and juvenile court service plans) for these 999 delinquent youthful offenders who were assessed during their youth for a variety of factors including demographic, offense history, mental health, substance use, child maltreatment, child welfare service involvement, and family environment (see Frederick (1999) for additional details regarding this baseline data collection). These youthful offenders were then assessed again (wave 2) at the time they would be 28 years of age to determine their involvement in criminal behaviors (see Colman et al. (2009) for additional details). It was during this second wave of data collection that the variable death from any cause was assessed.

\section{Our analytic database}

The analytic database used for this study combined the baseline data with the wave 2 outcome of early death. Since secondary data were used for this study none of the sampling, data collection, or measurement decisions were made by the current research team with the exception of the re-coding of the race/ethnicity variables.

\section{Measurement}

This research examines 16 explanatory variables informed by extant studies, including gender $($ male $=1)$ and race. Race, which originally included six classifications, and Latino ethnicity were combined to create three race/ethnicity indicator variables: (1) non-Hispanic White $(=1)$, (2) African-American (AfricanAmerican regardless of Latino ethnicity $=1$ ), and (3) Latino (non-African-American Hispanic $=1$ ). One non-Latino juvenile was coded missing for all three indicator variables because race was unknown. Data were incomplete regarding race or ethnicity for $N=14$ additional study participants; therefore, the final sample size for the race/ethnicity variables is $N=984$ and was $N=999$ for all other variables.

Family history of crime was coded as yes $=1$ if a youth's case file indicated that a 'parent or household member was known or suspected to be involved in criminal activity' (Colman et al., 2009, p. 28). Family history of substance abuse was measured via existing case records and coded as yes $=1$ if a parent or household member was known to be a substance abuser. Mental health functioning was measured at intake into OCFS via a 14-item mental health assessment which captured past and current mental health symptoms. This scale was then re-coded into a dichotomous variable $(0=$ no mental health need, $1=$ significant or substantial mental health need). Youth's substance abuse was assessed via a self-report screening 
instrument which collected information on alcohol, marijuana, and hard drug use during the 12 months proceeding OCFS contact. The substance use variable was converted to a four-point Likert scale with higher scores indicating more profound abuse. Data were missing for 10-15\% of the sample for the substance abuse variable; therefore, missing data were imputed for this variable using mean substitution based on sex, race, and geographic origin (rural, urban). The substance use variable was treated ordinally in the multivariate model.

Case records were also used to determine experience of maltreatment. New York State Child Care Review Service System (NYS CCRS) records were used to code youth who were physically abused or sexually abused by a parent, family member, or household member (yes $=1$ ). NYSCCR records were also used to dichotomously measure three other child welfare-related services received by the child after the age of 12 and their placement into OCFS. These variables only count services provided to the youth after age 12 due to limitations in the NYS CCRS database used. The three variables include, "ever received child welfare services' (yes $=1$ ), 'ever received foster care services' (yes $=1$ ), and 'received two or more child welfare placements after age 12' (yes $=1$ ).

Juvenile court records were also used to measure evidence of gang activity (yes $=1$ ) and to determine if youthful offenders were arrested for a weapons-related charge $(1=$ yes $)$. Onset of delinquency prior to age 14 was measured dichotomously (yes $=1$ ) and was used as a proxy for LCPs offender (Simons et al., 1994; Tibbetts \& Piquero, 1999).

Death prior to age 28 is the dependent variable. The database included information on whether or not the study participants died during the study duration (prior to age 28): Identifying information from all study participants including name, gender, race, date of birth, and social security were entered into the National Death Index $(1=$ deceased at follow-up $)$.

\section{Data analysis}

Independent variables for a multivariable model were identified by two approaches: (a) those significant in a bivariate analysis and (b) those available variables deemed important based on previous theories. To determine which independent variables were related to early death, stepwise logistic regressions were conducted. For the first model, the dependent variable early death was regressed on all 16 independent variables identified ((1-3) race/ethnicity as defined by non-Hispanic White, African-American, and Latino indicator variables, (4) gender, (5) weapons charge, (6) gang affiliation, (7) prior out of home placement for juvenile justice-related reasons, (8) mental health problems, (9) substance misuse, (10) history of sexual abuse, (11) history of physical abuse, (12) received child welfare services after age 12 , (13) foster care placement after age 12, (14) two or more foster care changes after age 12, (15) family or household substance abuse, and (16) family or household member with criminal history). Additionally, to determine if the risk factors for early death differ by gender, this process was repeated using the exact same variables for females (Model 2) and males (Model 3) separately. Due to potential concerns of small data cells, confirmatory, bootstrapped discriminant analyses on $80 \%$ samples $^{1}$ were also performed. The discriminant results confirmed the findings of the logistic models using the full data-set and therefore are not presented. Finally, binomial confidence intervals were constructed and Fisher's Exact tests 
were run to statistically compare our significant findings to the findings from similar studies.

\section{Results}

Out of a total of $N=999$ formerly detained youth who were followed into adulthood, $N=29(2.9 \%)$ were deceased at follow-up when they would have been 28 years of age (see Table 1 for information about the deceased youthful offenders). The deceased were predominantly male $(N=20,69 \%$ of deceased). Indeed, $4 \%$ of males died compared to $1.8 \%$ of sampled females. More African-Americans died $(N=17,59 \%$ of deceased) compared to non-Hispanic Whites $(N=9,31 \%$ of deceased) or Latinos $(N=3,10 \%$ of deceased $)$; however, a greater proportion of non-Hispanic Whites died $(3.9 \%)$ compared to African-Americans $(2.8 \%)$ or Latinos $(2.3 \%)$.

Of those who died, nearly $52 \%(N=15)$ had a family or household member with a criminal history. The deceased were also more likely to have a family or household member with a substance abuse problem $(N=21,72 \%$ of deceased). And, combined, $59 \%$ of the deceased indicated some level of substance misuse during the year prior to their arrest as a juvenile. These variables, although highly prevalent among the deceased, were not statistically significant in the bivariate or multivariable regression models (see Table 1 for bivariate results) because they had a high prevalence among the non-deceased as well.

Results from the first stepwise logistic regression which regressed early death on all 16 explanatory variables show that only one variable, gender, was statistically significant in predicting early death $(\mathrm{OR}=.44, \mathrm{CI}=.199-.978, p=.04)$. Being male made a juvenile 2.3 times more likely to die early compared to females.

The second model included only female respondents $(N=499)$ and regressed early death on the remaining 15 explanatory variables. The results reveal that compared to non-Hispanic Whites and Latino females, African-American females are 6.1 times less likely to experience early death $(\mathrm{OR}=.17, \mathrm{CI}=.03-.80, p=.03)$. The third model included only male respondents $(N=500)$ and regressed early death on the same 15 explanatory variables as Model 2. Results revealed no significant explanatory variables. Since there was only one explanatory variable significant in Models 1 and 2, and no significant variables in Model 3, and the odds ratios are presented in text above, the multivariable results are not presented in tabular form.

Our significant findings were then compared to findings from the existing literature. Three other studies evaluate the risk of death in early adulthood among US delinquent youthful offenders. Lattimore et al. (1997) uses a male only sample, Chassin et al. (2013) uses a sample that is $86 \%$ male, and Teplin et al. (2005) uses a stratified sample $(64.1 \%$ male). In the following sections, our findings are compared to these studies based first on race, then on gender, then on race and gender (see Table 2 for comparative risk of early death by race and gender).

\section{Comparison by race}

In the first model (Model 1) which regressed early death on all 16 variables, race was not statistically significant. Comparing death rates by race found here (AfricanAmerican, 2.8\%; non-Hispanic White, 3.9\%; and Latino, 2.3\%) to findings from Chassin et al., (African-American, 4.46\%; non-Hispanic White, 2.19\%; and Latino, 
Table I. Descriptive and bivariate analysess.

\begin{tabular}{|c|c|c|c|}
\hline \multirow[b]{2}{*}{ Group } & \multirow{2}{*}{$\begin{array}{l}\text { Group total } \\
n\end{array}$} & \multicolumn{2}{|c|}{ Died in group } \\
\hline & & $n$ & $\%$ died \\
\hline Females & 499 & 9 & 1.8 \\
\hline White non-Hispanic & 233 & 9 & 3.9 \\
\hline Latino & 133 & 3 & 2.3 \\
\hline African-American & 618 & 17 & 2.8 \\
\hline Less than 14 years of age & 438 & 10 & 2.2 \\
\hline Gang affiliation & 85 & 0 & .0 \\
\hline Weapons charge & 210 & 6 & 2.9 \\
\hline Family substance abuse & 632 & 21 & 3.3 \\
\hline History of sexual abuse & 165 & 5 & 3.0 \\
\hline History of physical abuse & 278 & 6 & 2.2 \\
\hline $\begin{array}{l}\text { Family or household member } \\
\text { with criminal history }\end{array}$ & 522 & 15 & 2.9 \\
\hline $\begin{array}{l}\text { Received child welfare services } \\
\text { after age } 12\end{array}$ & 552 & 13 & 2.4 \\
\hline $\begin{array}{l}\text { Received foster care services } \\
\text { after age } 12\end{array}$ & 361 & 10 & 2.8 \\
\hline $\begin{array}{l}\text { Two or more changes in foster care } \\
\text { placement after age } 12\end{array}$ & 279 & 5 & 1.8 \\
\hline Significant mental health need & 297 & 7 & 2.4 \\
\hline Self-reported substance abuse scale & & & \\
\hline 0 No problematic use & 388 & 12 & 3.1 \\
\hline 1 Less severe & 279 & 8 & 2.9 \\
\hline 2 Moderate severity & 251 & 7 & 2.8 \\
\hline 3 More severe & 81 & 2 & 2.5 \\
\hline
\end{tabular}


Died in

All other

comparison group

$n$

comparison

n.

500

756

865

371

532

914

789

367

834

721

477

447

638

720

702

$p$-value

4.0

2.7

3.1

3.2

3.5

3.2

2.9

2.2

2.9

3.2

2.9

14

16

3.6

19

3.0

.8508

.193

$24 \quad 3.3$

22

3.1

.0387

.3356

.6316

.6625

.2548

.1654

.9645

.2996

.915

.384

.9539

.2518

.65

$(.309,1.365)$

.928

$(.427,2.018)$

.529

$(.200,1.401)$

746

$(.315,1.766)$

.9898

.937

$(.640,1.374)$ 
Table 2. Comparison death rate.

\begin{tabular}{|c|c|c|c|c|c|c|c|c|}
\hline & & \multicolumn{3}{|c|}{$\begin{array}{l}\text { Current study } \\
\quad(N=984)\end{array}$} & \multirow{2}{*}{$\begin{array}{c}95 \% \mathrm{CI} \\
\text { (binomial based) }\end{array}$} & \multirow{2}{*}{$\begin{array}{c}\text { Teplin et al. }^{\mathrm{b}} \\
2005 \\
(N=1829) \\
\% \text { died }\end{array}$} & \multirow{2}{*}{$\begin{array}{c}\text { Chassin et al. }^{c} \\
2013 \\
(N=1354) \\
\% \text { died }\end{array}$} & \multirow{2}{*}{$\begin{array}{c}\text { Lattimore et al. }^{d} \\
1997 \\
(N=3995) \\
\% \text { died }\end{array}$} \\
\hline & & Total $N$ & $N$ died & $\%$ died & & & & \\
\hline \multirow[t]{4}{*}{ Males } & & 491 & 20 & 4.07 & $(2.5,6.2)$ & 4.35 & & \multirow[t]{12}{*}{4.53} \\
\hline & African-American & 308 & 15 & 4.87 & $(2.8,7.9)$ & 4.00 & & \\
\hline & White non-Hispanic & 112 & 4 & 3.57 & $(1.0,8.9)$ & 3.38 & & \\
\hline & Latino & 71 & 1 & 1.41 & $(.0,7.6)$ & 5.43 & & \\
\hline \multirow[t]{4}{*}{ Females } & & 493 & 8 & 1.62 & $(.7,3.2)$ & 2.13 & & \\
\hline & African-American & 310 & 2 & .65 & $(.1,2.3)$ & 1.63 & & \\
\hline & White non-Hispanic & 121 & 5 & 4.13 & $(1.4,9.4)$ & 2.25 & & \\
\hline & Latino & 62 & 2 & 3.23 & $(.4,11.2)$ & 3.65 & & \\
\hline \multirow[t]{4}{*}{ All } & & 984 & $2 \overline{8}$ & 2.85 & $(1.9,4.1)$ & 3.55 & 3.32 & \\
\hline & African-American & 618 & 17 & 2.75 & $(1.6,4.4)$ & 2.99 & 4.46 & \\
\hline & White non-Hispanic & 233 & 9 & 3.86 & $(1.8,7.2)$ & 3.04 & 2.19 & \\
\hline & Latino & 133 & 3 & 2.26 & $(.5,6.5)$ & 4.96 & 1.98 & \\
\hline
\end{tabular}

${ }^{a}$ Mean age at first placement in state custody 15 years; follow-up time frame is up to 28 years of age.

${ }^{b}$ Mean age at entry 14.9 years, follow-up time frame is 7.1 years.

${ }^{\mathrm{c}}$ Mean age at entry 16.5 years, follow-up time frame is 7 years.

${ }^{\mathrm{d}}$ Mean age at first arrest $13.55-14.20$ years, follow-up time frame $7-11$ years. 
$1.98 \%$ ) and Teplin et al. (2005) (African-American, 3.0\%; non-Hispanic White, $3.04 \%$; and Latino, $4.96 \%$ ) reveals some variation regarding who is at highest risk. Binomial confidence intervals were constructed for each race in our study and are presented in Table 2. Consistent with the results of the Fisher's Exact test (not shown), estimates from Teplin et al. (2005) and Chassin et al. (2013) fall within our confidence intervals and, therefore, are not significantly different from our results. This suggests that the differences in the percentages by race found between the three studies could be due to sampling error or differences in population demographics.

\section{Comparison by gender}

Chassin et al. (2013) did not delineate risk for premature death by gender as we have done here (Models 2 and 3). Teplin et al. (2005) did break down this risk by gender; however, they did not find a statistically significant difference in mortality by gender (females $=2.1 \%$ and males $=3.6 \%$ ), consistent with our findings. Lattimore et al.'s (1997) study included only males, and they reported a male death rate of $4.5 \%$. In our study, the death rate for females was $1.6 \%$ and for males it was $4.1 \%$. Binomial confidence intervals were constructed for each gender in our study and are presented in Table 2. Consistent with the results of the Fisher's Exact test (not shown), estimates from Teplin et al. (2005) and Lattimore et al. (1997) fall within our confidence intervals and, therefore, are not significantly different from our result. Once again, the differences in the percentage by gender between studies could be due to sampling error or differences in population demographics.

\section{Comparison by race and gender}

Teplin et al. (2005) broke down mortality risk by race and gender. Among females, Teplin et al. (2005) found the following rates of death (African-American, 1.63\%; non-Hispanic White, 2.25\%; and Latino, 3.65\%) compared to our findings for females (African-American, .6\%; non-Hispanic White, 4.1\%; and Latino, 3.2\%). Similarly, among males, Teplin et al. (2005) found the following death rate (African-American, 4.0\%; non-Hispanic White, 3.38\%; and Latino, 5.43\%) whereas we found the following rates for males (African-American, 4.9\%; non-Hispanic White, 3.6\%; and Latino, 1.4\%). A Fisher's exact test revealed that these differences between Teplin and the current study were not statistically significant. These comparisons suggest that some of the variations in death rates by race and gender may be explained by sampling error or sampling variation in these samples (Teplin et al. and ours).

\section{Discussion}

Findings from this research offer some important information to enrich the somewhat limited body of knowledge about factors associated with death in early adulthood by individuals who were delinquent and incarcerated as adolescents. In this sample, $N=29(2.9 \%)$ formerly delinquent and incarcerated youthful offenders died before age 28 . This is a comparable rate of early death seen in similar delinquent population research (Chassin et al., 2013; Teplin et al., 2005), and is substan- 
tially higher than the mortality rate for non-delinquent young adults (Teplin et al., 2005). When analyzing the total sample, (Model 1) only one variable, gender, was significantly related to early death. Four percent of males was deceased at followup $(N=20)$, which is significantly higher than for females $(N=9,1.8 \%)$. More of the deceased were African-American $(N=17)$ compared to other races, and nonHispanic Whites had the highest rate of death $(3.9 \%$ died). In the second model, African-American females were found to be 6.1 times less likely to experience early death compared to non-Hispanic White females and Latino females. Analysis did not reveal any statistically significant racial difference in early death among the full sample or among males. Our findings, when compared to other findings found in the existing literature, reveal no statistically significant differences by race, by gender, or by race and gender. These comparisons suggest that some of the variation in death rates by race, by gender, and by race and gender may be explained by sampling error or sampling variation in these samples.

\section{Other factors}

Some variables closely related to risk factors (gang activity, violence/gun carrying, and substance misuse) that previous studies have found to be related to early death (Chassin et al., 2013; Lattimore et al., 1997) were not found to be significant in our study. It is unknown if these variables truly were not factors present in the lives of the delinquent youthful offenders studied, or perhaps these variables were not significant due to variation in the way these variables were assessed. For example, some measurements of the variables were collected differently in this study (via existing case records from youthful offenders) compared to how they were measured in Chassin et al. (2013) (via self-report). In addition, the sample used in this study included incarcerated youthful offenders; the comparable studies did not exclusively study incarcerated youthful offenders, but also included those that may have been only detained or probation-supervised.

\section{Limitations and strengths}

There are some important limitations to this research. First, the sampling frame for this research only includes youth who were placed in residential custody, primarily incarceration facilities, which represents only a fraction of the entire delinquent youthful offender population. Indeed, a majority of delinquent youthful offenders are not placed in secure residential placements. Additionally, although the number of death events in this study is similar to those reported in comparable studies, a second limitation is the small number of subjects who died during the follow-up period. A total of $N=29$ subjects (out of 999) were deceased at follow-up which is $2.9 \%$ of the total sample. While this number is high compared to the general population, it is a small number in terms of providing robust statistical power due to low variability of the dependent variable. Another limitation is the reliance on secondary data. Some potentially interesting variables were not available for inclusion, and several of the variables were not measured in an ideal fashion. For example, the child welfare variables only measured the youth's experiences after the age of 12. It is likely that some of the youthful offenders in the study had child welfarerelated experiences earlier in their youth. Similarly, the gang affiliation variable is limited to the information available, which may under-represent actual gang 
involvement. A related limitation is that more detail was not available regarding measurement of the substance abuse and mental health variables. Finally, this sample was exclusively drawn from the state of New York which limits the generalizability of the findings. Nevertheless, this study adds to the existing knowledge since Lattimore et al. (1997) uses only California data, Teplin et al. (2005) uses only Cook County, Illinois data, and Chassin et al. (2013) used data from only two counties (one in Pennsylvania and one in Arizona). The comparable results (regarding race and gender) across these studies conducted in different geographic locations across the United States add strength to the overall findings of this study as well as the other studies.

\section{Future research and implications}

This research has provided meaningful information regarding the factors associated with short-term mortality among a sample of formerly incarcerated youth. Of particular interest, in this sample, African-American women experienced lower mortality compared to others. Future research should investigate if protective factors may be present in the lives of these women, or specifically what might explain the lower death rate among African-American young women in this study. For example, assessment of ongoing exposure to individual and community-level risk factors should be included in future studies. Future research will help the scientific community determine if these findings are a true indication of resiliency among this group, and if so, what can be done to extend this resiliency to other sub-groups.

This research also clearly points to the increased risk of early death among males studied. Future research is needed to better understand this risk. Since all of the youth studied were at one time in residential custody, it makes sense to consider what we know about the outcomes of these types of interventions in hopes of increasing the support for those youth who are most at risk. It also makes sense to consider what policy changes should be made to help modify the life course for all high-risk offending youth, particularly males who are at the highest risk. We know that a small number of youthful offenders may pose such a significant community risk that incarceration is the only available disposition. When incarceration is the only alternative, these placements should be short-term, rehabilitative-focused, and include a re-entry plan for reintegration with the adolescents' community (Mallett, 2012). It must be emphasized that facilities for youth must be safe and focus on rehabilitation rather than punishment and control (Mendel, 2012). Research indicates that serious youthful offending can be minimized and incarceration recidivism decreased through these efforts (Mallett, 2012). It stands to reason that these interventions may also be helpful in decreasing the risk factors associated with early death, although this must be confirmed by research.

Rehabilitative alternatives and programs that are effective in rehabilitating incarcerated youthful offenders have a number of common components: supportive social contexts including authoritative adults, a focus on changing problem behaviors, and interventions that improve the adolescents' psychosocial maturity (Scott \& Steinberg, 2008). These programs must be appropriately designed, of high quality, and of sufficient duration to improve youthful offender outcomes (Lipsey, 2009). Some effective rehabilitative efforts include Aggression Replacement Training, cognitive-behavioral therapy, effective quality education, counseling and group therapy, and behavior modification programs (Armeluis \& Andreassen, 2007). 
Additionally, it is well recognized within the juvenile justice system that small, community-based corrections facilities, compared to large, punitively focused facilities, are far more effective in improving youthful offender outcomes. These smaller facilities keep youthful offenders closer to their homes and communities and provide rehabilitative programming. While numerous states are decreasing youthful offender incarceration rates for various reasons, many are not changing the institutional structure or paradigm (Justice Policy Institute, 2013). If we want all youthful offenders to have a chance post release to avoid the risk factors associated with ongoing criminal activity and potentially early death outcomes, incarceration and juvenile justice system reform must continue, particularly for males who have the highest risk for early death. Future research should assess the influence of different intervention approaches on the risk for early death, and if offender's needs might differ based on race and gender.

This research also reveals many factors that were not found to be predictive of early death. Of surprise, factors such as gang involvement and weapons charges were not found to be significant in this study. It is prudent to study the former delinquent's ongoing exposure to these and other risk factors in future studies. Determining the cause of death for each deceased youth would strengthen future research. Similarly, early risk factors measured would benefit from corroboration (e.g. the juvenile courts, the police, schools, and mental health professionals). Another risk factor that should be measured prospectively is medical problems and access and use of regular health care. Future research should continue to assess the risk of premature death throughout the normal life span in this sample.

\section{Note}

1. It is conventional to use a subset of the sample to validate results when over-modeling or sparse cells may be suspected (Diaconis \& Efron, 1983).

\section{Notes on contributors}

Patricia Stoddard-Dare earned her PhD from the George Warren Brown School of Social Work at Washington University in St. Louis where she also completed a mental health services research fellowship for the National Institute of Mental Health. Currently, she is an associate professor of Social Work at Cleveland State University. In addition to teaching courses in program evaluation, research methods, and substance abuse, she is the co-coordinator of the Chemical Dependency Counseling Certificate Program. She has published over a dozen articles pertaining to the intersection of juvenile delinquency and gender, race, child abuse, substance abuse, mental health difficulties, and educational disabilities.

Miyuki Fukushima Tedor received her $\mathrm{PhD}$ in sociology from the University of Oklahoma and is now an assistant professor at Cleveland State University in the Department of Sociology and Criminology. Her research focuses on testing theories of crime at the micro level, both across gender and across nation, specifically between Japan and the US. Using theories of crime, she has examined deviant behaviors among youth, including alcohol and drug use and academic cheating. She is the author of seven publications.

Linda Quinn is an applied statistician. In addition to her PhD, she has Master degrees in applied statistics, computer science, and operations research. She is a full-time faculty member in the Mathematics department at Cleveland State University. She is the author or 27 publications focusing on statistical ethics, health policy, clinical trials, trauma, and juvenile delinquency. Her research interests include statistical collaborations in applied disciplines, research methods, and clinical trials. 
Christopher Mallett is an associate professor and BSW program director. He teaches research methods, statistics, program evaluation, and mental health policy graduate and undergraduate courses in the School of Social Work at Cleveland State University. His research focuses on children and adolescents with disabilities and their involvement with the mental health system, school districts (special education), child welfare, and juvenile courts, with a focus on the impact of comorbid problems and juvenile justice system outcomes. He has published over 40 journal papers and book chapters, as well as a textbook, on these topics.

\section{References}

Abram, K. M., Teplin, L. A., McClelland, G. M., \& Dulcan, M. K. (2003). Comorbid psychiatric disorders in youth in juvenile detention. Archives of General Psychiatry, 60, 1097-1108.

Acoca, L. (1998). Outside/inside: The violation of American girls at home, on the streets, and in the juvenile justice system. Crime and Delinquency, 44, 561-589.

Armeluis, B. A., \& Andreassen, T. H. (2007). Cognitive-behavioural treatment for antisocial behavior in youth in residential treatment. Oslo: The Campbell Collaboration.

Bartusch, D. R., Jeglum, D. R. L., Moffitt, T. E., \& Silva, P. A. (1997). Is age important? Testing a general versus a developmental theory of antisocial behavior. Criminology, 35, $13-48$.

Bender, K. (2009). Why do some maltreated youth become juvenile offenders? A call for further investigation and adaption of youth services. Children Youth Services Review, $32,466-473$.

Binswanger, I., Stern, M., Deyo, R., Ingrid, A., Binswanger, M. D., Marc, F., ... Koepsell, M. D. (2007). Release from prison - A high risk of death for former inmates. New England Journal of Medicine, 356, 157-165.

Chassin, L., Piquero, A., Losoya, S., Mansion, A., \& Schubert, C. (2013). Joint consideration of distal and proximal predictors of premature mortality among serious juvenile offenders. Journal of Adolescent Health, 1-8.

Colman, R., Kim, D. H., Mitchell-Herzfeld, S., \& Mitchell-Herzfeld T. (2009). Long-term consequences of delinquency: Child maltreatment and crime in early adulthood. National Institute of Justice (NCJ Number 226577). Rockville, MD: National Institute of Justice/ NCJRS. Retrieved from https:/www.ncjrs.gov/App/Publications/abstract.aspx? $\mathrm{ID}=248572$

Corneau, M., \& Lanctot, N. (2004). Mental health outcomes of adjudicated males and females: The aftermath of juvenile delinquency and problem behaviour. Criminal Behaviour and Mental Health, 14, 251-262.

Cravioto, J., \& Arrieta, R. (1983). Malnutrition in childhood. In M. Rutter (Ed.), Developmental neuropsychiatry (pp. 32-51). New York, NY: Guilford Press.

Diaconis, P., \& Efron, B. (1983). Computer-intensive methods in statistics. Scientific American, May, 116-130.

Epstein, J. A., \& Spirito, A. (2009). Risk factors for suicidality among a nationally representative sample of high school students. Suicide and Life-Threatening Behavior, 39, 241-251.

Ezell, M., \& Cohen, L. (2005). Desisting from crime: Continuity and Change in Long-term Crime Patterns of Serious Chronic Offenders. Oxford, UK: Oxford University Press.

Ford, J. D., Chapman, J. F., Hawke, J., \& Albert, D. (2007). Trauma among youth in the juvenile justice system: Critical issues and new directions. Delmar, NY: National Center for Mental Health and Juvenile Justice.

Frederick, B. (1999). Factors contributing to recidivism among youth placed with the New York state division for youth. Renesselaer, NY: Office of Justice Systems Analysis Research Report. New York State Division of Criminal Justice Services.

Goldstein, N., Olubadewo, O., Redding, R., \& Lexcen, F. (2005). Mental health disorders: The neglected risk factor in juvenile delinquency. In K. Heilbrum (Ed.), Juvenile delinquency: Prevention, assessment and intervention (pp. 85-110). New York, NY: Oxford University Press.

Grisso, T. (2008). Adolescent offenders with mental disorders. The Future of Children, 18, $143-162$. 
Hamilton, C. E., \& Browne, K. D. (1998). The repeat victimization of children: Should the concept be revised? Aggression and Violent Behavior, 3, 47-60.

Hamilton, C. E., Falshaw, L., \& Browne, K. D. (2002). The link between recurrent maltreatment and offending behavior. International Journal of Offender Therapy and Comparative Criminology, 46, 75-94.

Harrell, E. (2007). Special Report Black victims of violent crime (NCJ 214258). Washington, DC: US. Department of Justice, Office of Justice Programs, Bureau of Statistics. Retrieved from http://bjs.ojp.usdoj.gov/content/pub/pdf/bvvc.pdf

Hertzig, M. (1983). Temperament and neurological status. In M. Rutter (Ed.), Developmental neuropsychiatry (pp. 164-180). New York, NY: Guilford Press.

Holsinger, K., \& Holsinger, A. (2005). Differential pathways to violence and self-injurious behavior: African American and white girls in the juvenile justice system. Journal of Research in Crime and Delinquency, 42, 211-242.

Howell, J. C. (2003). Preventing \& reducing juvenile delinquency: A comprehensive framework. Thousand Oaks, CA: Sage.

Johnson, J. (2003). Fundamentals of substance abuse practice. Belmont, CA: Brooks Cole.

Johnson-Reid, M., \& Barth, R. P. (2000). From maltreatment report to juvenile incarceration: The role of child welfare services. Child Abuse and Neglect, 24, 505-520.

Justice Policy Institute. (2013). Common ground: Lessons learned from five states that reduced juvenile confinement by more than half. Washington, DC: The Annie E. Casey.

Kandel, E., \& Mednick, S. A. (1991). Prenatal complications predict violent offending. Criminology, 29, 519-530.

Krinsky, C., Lathrop, S., Brown, P., \& Nolte, K. (2009). Drugs, detention, and death: A study of the mortality of recently released prisoners. American Journal of Forensic Medical Pathology, 30, 6-9.

Lattimore, P. K., Linster, R. L., \& MacDonald, J. M. (1997). Risk of death among serious young offenders. Journal of Research on Crime and Delinquency, 34, 187-209.

Laub, J., \& Sampson, R. J. (2003). Shared beginnings, divergent lives: Delinquent boys to age 70. Cambridge, MA: Harvard University Press.

Laub, J. H., \& Valliant, G. E. (2000). Delinquency and mortality: A 50-year follow-up study of 1,000 delinquent and nondelinquent boys. American Journal of Psvchiatry, 157, $96-102$.

Lemmon, J. H. (2006). The effects of maltreatment recurrence and child welfare services on dimensions of delinquency. Criminal Justice Review, 31, 5-32.

Lipsey, M. W. (2009). The primary factors that characterize effective interventions with juvenile offenders: A meta-analytic overview. Victims and Offenders, 4, 124-147.

Loeber, R., Kalb, L., \& Huizinga, D. (2001). Juvenile delinquency and serious injury victimization. Washington, DC: Office of Juvenile Justice and Delinquency Prevention, US Department of Justice.

Mallett, C. A. (2012). Linking disorders to delinquency: Treating high-risk youth in the juvenile justice system. Boulder, CO: First Forum Press/Lynn Rienner.

Mendel, R. A. (2012). No place for kids: The case for reducing juvenile incarceration. Baltimore, MD: The Annie E. Casey Foundation.

Mernard, S. (2002). Short- and long-term consequences of adolescent victimization. Washington, DC: Office of Juvenile Justice and Delinquency Prevention, US Department of Justice.

Milner, J. S., \& McCanne, T. R. (1991). Neuropsychological correlates of physical child abuse. In J. S. Milner (Ed.), Neuropsychology of aggression (pp. 131-145). Norwell, MA: Kluwer Academic.

Moffitt, T. E. (1993). Adolescent-limited and life-course-persistent antisocial behavior: A developmental taxonomy. Psychological Review, 100, 674-701.

Moffitt, T. E. (2003). Life-course-persistent and adolescence-limited antisocial behavior: A 10-year research review and a research agenda. In B. B. Lahey, T. E. Moffitt, \& A. Capsi (Eds.), Causes of conduct disorder ad juvenile delinquency (pp. 49-75. New York, NY: Guilford.

Moffitt, T. E., Capsi, A., Rutter, M., \& Silva, P. A. (2001). Sex differences in antisocial behavior: Conduct disorder, delinquency, and violence in the Dunnedin longitudinal study. Cambridge: Cambridge University Press. 
Moffitt, T. E., Caspi, A., Harrington, H. L., \& Milne, B. J. (2002). Males on the life-coursepersistent and adolescence-limited antisocial pathways: Follow-up at age 26 years. Development and Psychopathology, 14, 179-207.

Nagin, D. S., Farrington, D. P., \& Moffitt, T. E. (1995). Life-course trajectories of different types of offenders. Criminology, 33, 111-139.

National Center for Child Traumatic Stress. (2009). Child sexual abuse: Coping with the emotional stress of the legal system. Los Angeles, CA: UCLA.

National Institute of Mental Health. (2012). Suicide: A major preventable mental health problem - facts about suicide and suicide prevention among teens and young adults. Rockville, MD: National Institute of Mental Health.

Needleman, H. L., \& Beringer, D. C. (1981). The epidemiology if low-level lead exposure in childhood. Journal of Child Psychiatry, 20,496-512.

Nieuwbeerta, P., \& Piquero, A. (2008). Mortality rates and causes of death of convicted Dutch criminals 25 years later. Journal of Research in Crime and Delinquency, 45, 256-286.

Odgers, C. L., Caspi, A., Broadbent, J. M., Dickson, N., Hancox, R. J., Harrington, H. L., Poulton, R., Sears, M. R., Thomson, W. M., \& Moffitt, T. E. (2007). Prediction of differential adult health burden by conduct problem subtypes in males. Archives of General Psychiatry, 64, 476-484.

Piquero, A. R., Daigle, L. E., Piquero, N. L., \& Tibbetts, S. G. (2007). Research note: Are life-course-persistent offenders at risk for adverse health outcomes? Journal of Research in Crime and Delinquency, 44, 185-207.

Piquero, A. R., Farrington, D. P., Nagin, D. S., \& Moffitt, T. E. (2010). Trajectories of offending and their relation to life failure in late middle age: Findings from the Cambridge study in delinquent development. Journal of Research in Crime and Delinquency, 47, 151-173.

Piquero, A. R., MacDonald, J., Dobrin, A., Daigle, L. E., \& Cullen, F. T. (2005). Self control, violent offending, and homicide victimization: Assessing the general theory of crime. Journal of Quantitative Criminology, 21, 55-71.

Piquero, A. R., \& Moffitt, T. E. (2005). Explaining the facts of crime: How the developmental taxonomy replies to Farrington's invitation. In D. P. Farrington (Ed.), Integrated developmental and life-course theories of offending: Advances in criminological theory (Vol. 14, pp. 51-72). New Brunswick, NJ: Transaction.

Piquero, A. R., Shepherd, I., Shepherd, J. P., \& Farrington, D. P. (2011). Impact of offending trajectories on health: Disability, hospitalisation and death in middle-aged men in the Cambridge study in delinquent development. Criminal Behaviour and Mental Health, 21, 189-201.

Rodning, C., Beckwith, L., \& Howard, J. (1989). Characteristics of attachment organization and play organization in prenatally drug-exposed toddlers. Development and Psychopathology, 1, 277-289.

Romanov, K., Hatakka, M., Keskinen, E., Laaksonen, H., Kaprio, J., Rose, R. J., \& Koskenvuo, M. (1994). Self-reported hostility and suicidal acts, accidents and accidental deaths: A prospective study of 21,443 adults aged 25-59. Psychosomatic Medicine, 56, 328-336.

Sampson, R. J., \& Laub, J. (2005). A life-course view of the development of crime. Annals of the American Academy of Political and Social Science, 602, 12-45.

Scott, E. S., \& Steinberg, L. (2008). Adolescent development and the regulation of youth crime. The Future of Children, 18, 16-33.

Sedlak, A. J., \& McPherson, K. (2010). Survey of youth in residential placement: Youth s needs and services. Washington, DC: Westat Corporation.

Shelton, D. (2004). Experiences of detained young offenders in need of mental health care. Journal of Nursing Scholarship, 36, 129-133.

Shufelt, J. L., \& Cocozza, J. J. (2006). Youth with mental health disorders in the juvenile justice system: Results from a multi-state prevalence study. Delmar, NY: National Center for Mental Health and Juvenile Justice.

Siminoff, E., Elander, J., Holmshaw, J., Pickles, A., Murray, R., \& Rutter, M. (2004). Predictors of antisocial personality: Continuities from childhood to adult life. British Journal of Psychiatry, 184, 118-127. 
Simons, R. L., Wu, C.-I., Conger, R. D., \& Lorenz, F. O. (1994). Two routes to delinquency: Differences between early and late starters in the impact of parenting and deviant peers. Criminology, 32, 247-276.

Smith, C. A., Ireland, T. O., \& Thornberry, T. P. (2005). Adolescent maltreatment and adolescent involvement in delinquency. Child Abuse and Neglect, 29, 1099-1119.

Smith, C. A., \& Thornberry, T. O. (1995). The relationship between childhood maltreatment and adolescent involvement in delinquency. Criminology, 33, 451-481.

Spaulding, A., Ryan, M., Seals, V., McCallum, S., Perez, A., \& Brzozowski, Steenland, N. (2011). Prisoner survival inside and outside of the institution: Implications for healthcare planning. American Journal of Epidemiology, 173, 479487.

Stewart, A. (1983). Severe perinatal hazard. In M. Rutter (Ed.), Developmental neuropsychiatry (pp. 15-31). New York, NY: Guilford Press.

Stouthamer-Loeber, M., Wei, E. H., Homish, D. L., \& Loeber, R. (2002). Which family and demographic factors are related to both maltreatment and persistent serious juvenile delinquency? Children's Services: Social Policy, Research, and Practice, 5, 261-272.

Teplin, L. A., McClelland, G. M., Abram, K. A., \& Mileusnic, D. (2005). Early violent death among delinquent youth: A prospective longitudinal study. Pediatrics, 115, $1586-1593$.

Thompson, M., Ho, C., \& Kingree, J. (2007). Prospective associations between delinquency and suicidal behaviors in a nationally representative sample. Journal of Adolescent Health, 40, 232-237.

Tibbetts, S. G., \& Piquero, A. R. (1999). The influence of gender, low birth weight, and disadvantaged environment in predicting early onset of offending: A test of Moffitt's interactional hypothesis. Criminology, 37, 843-877.

Trumbetta, S. L., Seltzer, B. K., Gottesman, I. I., \& McIntyre, K. M. (2010). Mortality predictors in a 60-year follow-up of adolescent males: Exploring delinquency, socioeconomic status, IQ, high-school drop-out study and personality. Psychosomatic Medicine, $72,46-52$.

Yeager, C. A., \& Lewis, D. O. (1990). Mortality in a group of formerly incarcerated juvenile delinquents. American Journal of Psychiatry, 147, 612-614.

Zahn, M. A., Agnew, R., Fishbein, D., Miller, S., Winn, D., Dakoff, G., ... Chesney-Lind, M. (2010). Girls study group: Causes and correlates of girls' delinquency. Washington DC, Office of Juvenile Justice and Delinquency Prevention, Office of Justice Programs, US Department of Justice. 
Copyright of Criminal Justice Studies is the property of Routledge and its content may not be copied or emailed to multiple sites or posted to a listserv without the copyright holder's express written permission. However, users may print, download, or email articles for individual use. 